LegGatt, P. O. and Walton, E. W. (1956): Wegener's Granulomatosis, Thorax, II, 94.

MOORE, P. M., BEARD, E. E., Thoburn, T. W., and Williams, H. L. (I95I): Idiopathic (lethal) Granuloma of Mid-line Facial Tissues Treated with Cortisone-Report of a Case, Laryngoscope (St. Louis), 6r, 320.

Walton, E. W. (1958): Giant Cell Granuloma of the Respiratory Tract (Wegener's Granulomatosis), Brit. med. F., $\stackrel{\mathbb{Q}}{\mathcal{Q}}$ ii, 265 .

(1959): Non-healing Granulomata of the Nose, F. Laryng., 73, 242.

WEGENER, F. (1936): Uber generalisierte septische Gefässerkrangungen, Verh. dtsch. Path. Ges., 29, 202.

- (1939): Uber eine eigenartige rhinogene Granulomatose mit besondere Beteiligung des Arterien-systems und der Nieren, Beitr. path. Anat., 102, 36.

Weinberg, T. (1946): Periarteritis Nodosa in Granuloma of Unknown Ætiology; Report of 2 Cases, Amer. F. clin. Path., 16, 784.

\title{
FATAL APLASTIC ANAEMIA FOLLOWING SULPHAPHENAZOLE (ORISULF) THERAPY
}

\author{
Frank Spracklen, M.B., Ch.B., M.R.C.P. \\ Medical Registrar, Westminster Hospital, London, S.W.I
}

WiNTROBE (196r) classifies sulphonamides among the rarer causes of pancytopenia. Nevertheless, aplastic anæmia due to sulphonamides occurred in $5.3 \%$ of Welch's series (Welch, Lewis and Kerlan 1954), $8.7 \%$ of Wolff's 334 cases (Wolff and others I.959), and once in Scott's series of 39 cases (Scott, Cartwright and Wintrobe 1959). Similarly the shorter-acting sulphonamide preparations have appeared individually in the literature from time to time as causing aplastic anæmia viz. sulphathiazole (Strauss, 1943; Meyer and Perlmutter, 1942), sulphanilamide and sulphadiazine (Denny and Menten, 1946), sulphabutin (Wagner and Sterz, r96I), and sulphapyridine (Scott and others, r959). The sulphonated nitrobenzene nucleus of the sulphonamide compounds has been blamed for the bone marrow depression and this indeed would seem to be the case, as structurally related compounds like carbutamide, tolbutamide, acetazolamide and thiosemicarbazone have all been associated with the development of aplastic anæmia. (see Wintrobe (196r) for references).

There have, however, been few reports of this complication following the use of the newer, longer acting sulphonamides.

The first of these drugs, sulphamethoxypyridazine was first reported to have caused aplastic anæmia in 1958 (Holsinger, Hanlon and Welch). A further report followed in $196 \mathrm{I}$ (Johnson and Korst).

A sulphonamide with a similar prolonged action is 3-(p-amino benzene sulphonamido)-2-phenylpyrazole (sulphaphenazole, 'orisulf', 'orisul') which has the following structural formula:-

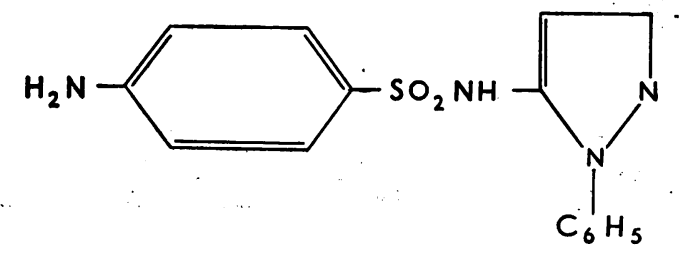

The case reported here suggests a possible $\underset{\infty}{\stackrel{\infty}{\infty}}$ association between the administration of this 0 drug and the development of aplastic anæmia.

\section{Case Report}

The patient was a 66 -year-old housewife who lived in Jersey. For 15 years she had suffered from asthma $\stackrel{5}{+}$ and chronic bronchitis. On May 26, 196r, she wegt $\vec{\bullet}$ to see her general practitioner with breathlessness of which had not responded to aminophyllin and ephedrine. Severe bronchospasm was diagnosed and betame thazone prescribed; initially $2 \mathrm{mg}$ was given daily $\mathrm{m}$. divided doses, reducing to $0.5 \mathrm{mg}$ daily by the roth June, 196I when 'Amesec' was introduced.

In July 1961 a diagnosis of acute bronchitis was made and a 4 day course of 'Orisulf' given $-1 \mathrm{~g}$ twice $\mathbb{D}$ a day for the first 2 days, and $0.5 \mathrm{~g}$ twice a day for the next two.

The patient was next seen by her doctor on August 3 16, 196I when she had had no drugs for 4 weeks. She had been feeling well but petechiæ were noticed by the $\overline{0}$ doctor. Ascorbic acid was given pending investigation.

Early in October 1961, in addition to petechiz in the 윽 skin and hard palate, there were ecchymoses in the 3 skin and Hess's test was strongly positive. At this time the patient was receiving Histryl spansules 3 . (Diphenylpyraline hydrochloride) for vasomotor rhinitis.

Blood count: Hb. $62 \%$; wbc 4,700/cu.mm.; 옹 polymorphs $30 \%$, eosinophils $6 \%$, lymphocytes $63 \%$, monocytes $1 \%$, PCV $30 \%$; MCHC $30.5 \%$, platelets 음 220,000/cu.mm.

On October 25, I $196 \mathrm{I}$ the patient was admitted to the $\frac{7}{2}$ General Hospital, Jersey. A few days before her admission she had become lethargic and anorexic and $N$ had developed soreness of the tip of her tongue. A further blood count showed: $\mathrm{Hb} .26 \%$; wbc $3,200 \% \mathrm{~N}$ cu.mm.; reticulocytes $0.3 \%, \mathrm{PCV} 13 \%$; MCHC $29.5 \%$; N ESR $75 \mathrm{~mm}$ hr (Wintrobe). The sternal marrow was hypoplastic and acellular. An occasional normoblast was present. One myelocyte was seen in $201 / 12$ incho fields.

In addition to blood transfusions, ACTH, prednisone, iron, ascorbic acid and Vitamin $B_{12}$ were given. On? February i2, 1962, the patient was transferred to the Westminster Hospital for consideration of bone marrow infusion. 
On admission the patient was clinically anæmic and there were numerous petechiæ and ecchymoses, especially over upper chest anteriorly, forearms, and buttocks. Petechiæ were seen on the conjunctivæ, buccal mucosa and pharynx. Hess's test was strongly positive. The blood pressure was $140 / 85 \mathrm{~mm} \mathrm{Hg}$ and a soft systolic murmur was audible at the mitral area.

Investigations: Blood urea: $40 \mathrm{mg} / 100 \mathrm{ml}$. $\mathrm{Hb}$ : $54 \%$, Reticulocytes less than $\mathrm{I} \%$, rbc $2,360,000 /$ cu.mm. wbc 3,500/cu.mm. (differential count: neutrophils $16 \%$, lymphocytes $83 \%$, monocytes $1 \%$ ) ESR 62 $\mathrm{mm} / \mathrm{hr}$ (Wintrobe); PCV 26\%; MCV 1 10 cu. $\mu$; MCHC $33 \%$.

The bone marrow was very hypoplastic. The total nucleated count was 38,000 cells per cu.mm. The film showed predominantly lymphocytes with an occasional plasma cell. One myelocyte and one nucleated red cell seen. Megakaryocytes were not seen.

Course in Hospital-20 units ACTH were given on February 15, I962 and on the following day bone marrow was collected from the patient's I6-year-old grandson by multiple bone marrow punctures under general anæsthesia using the technique described by Pegg and Kemp (1960). $300 \mathrm{ml}$ of bone marrow-blood mixture was administered by intravenous infusion. From the day of infusion, prednisone $50 \mathrm{mg}$. daily in divided doses was given. On February 21, I962 a further 20 units ACTH were given.

Between March 10-21, 1962 the patient received 6 pints of blood. On March 27 hæmaturia was noted and there was generalised abdominal tenderness. Despite blood transfusion, methicillin and hydrocortisone the patient deteriorated rapidly and died on April 2, 1962 .

At autopsy, extensive hæmorrhages were found in the tonsillar fossæ, aryepiglottic folds and pyriform fossæ. There was a large retroperitoreal hæmorrhage arising from both kidneys. Histologically, the bone marrow of the sternum showed almost complete aplasia with many foci of plasma cells and macrophages.

\section{Discussion}

Sulphaphenazole has always enjoyed an excellent reputation. An extensive comparative study of sciphaphenazole and five other sulphonamides in luding sulphamethoxypyridazine was carried out at the CIBA laboratories by Neipp, Padowetz, Sackmann and Tripod, 1958). They showed that sulphaphenazole gave the best-sustained blood concentrations in several animal species, had the best therapeutic effect on mice infected with streptococci and at the same time showed the lowest blood concentrations. The use of $1.0 \mathrm{~g} / \mathrm{kg}$. of sulphaphenazole daily for 28 days in rats resulted in no pathological changes in these animals.

Clinical studies followed in man and Essellier, Hunziker and Goldsand (1958) reported that side effects were rare. I74 patients were studied; inclusion bodies were seen in 3 , nausea in 'an occasional patient' and urticaria and Quincke's œdema in I case each. Orisulf was given to 3 allergic patients but no allergic manifestations followed its use.

Further clinical trials, involving $38 \mathrm{I}$ patients in all, showed that the drug was apparently free from toxic and allergic sequelæ while exhibiting a high degree of therapeutic efficiency (Brockhaus, 1958; Rentchnick,'1958; Susset, 1958; Wheatley, 1959). A search through the literature has failed to reveal a case of aplastic anæmia due to or following the administration of sulphaphenazole. The use of sulphonamides in the prevention of recurrences of rheumatic fever is accepted by many (Rosenberg and Hench, 1946). The longeracting sulphonamides seem logical contenders for a place in this type of prophylaxis and indeed sulphamethoxypyridazine has been suggested for this purpose by Lepper, Simon and Marienfeld (1957), Schultz and Frank (1958), and Johnson, Matthews and Stollerman (I95,). In fact Lepper and his colleagues found one dose per week adequate. Brockhaus (1958) regarded sulphaphenazole as being especially suited to the prophylaxis of rheumatic diseases.

Wheatley (1959) suggests the possible use of this drug in the prophylactic treatment of chronic bronchitis.

The high incidence of toxicity with sulphamethoxypyridazine would appear to make its long term use undesirable. Perhaps, therefore, as sulphaphenazole and the still newer sulphadimethoxine are more widely used, further cases of bone marrow depression will occur and be reported.

The mechanism by which sulphonamides produce marrow aplasia is, however, incompletely understood. While direct toxicity seems frequently to be responsible, interest in an allergic or autoimmune type of reaction was aroused by the clinical impression that manifestations of allergy are common in patients with aplastic anæmia (Osgood, 1953, and Wolff, 1957).

Wolff (1957) in his series of 334 cases of aplastic anæmia found an incidence of $21.4 \%$ of allergy in all cases, but of $62.4 \%$ in thoses cases induced by antibacterial agents. In addition the incidence of an allergic family history was three times as great in the latter group.

It is therefore of some interest that this patient is said to have been an asthmatic and an allergic subject.

Osgood (1953) has postulated that the drug or its metabolite producing the aplastic anæmia behaves as a haptene. Such a mechanism has been demonstrated in thrombocytopenia due to sedormid (Ackroyd, 1949) quinidine (Hirsch and Dameshek, 1950) and other drugs (Beutler, Robson and Bultenwiesser, 1957) and in agranulocytosis due to pyramidon (Mœschlin, Siegenthaler, Gasser and Hassig, 1954).

It seems possible that the demonstration of cytoagglutinins in a few cases of aplastic anæmia (Dausset, Nenna and Brecy, 1954, Dausset, Nenna, Tsevrenis and Bernard 1953; Mœschlin and others 1954a; Matoth, Elian, Nelken and Nevo, 1956; von Weinreich and Muller, 1956), might support a similar mechanism in aplastic anæmia, as suggested by Scott and others (1959).

Although definite proof is lacking it seems at least likely that the aplastic anæmia which this patient developed was due to sensitivity to sulphaphenazole. It is suggested, therefore, that the 
routine use of this drug in potentially allergic subjects, e.g. asthmatics, be discontinued.

\section{Summary}

A case of aplastic anæmia following upon the use of sulphaphenazole ('Orisulf') is reported. It is believed to be the first case of aplastic anæmia associated with this drug to be published. The literature is briefly reviewed and it is suggested $\varrho$ that the use of this drug in allergic subjects be $\frac{\pi}{\infty}$ avoided.

I wish to thank Dr. R. D. Tonkin (under whose care $\overrightarrow{\bar{F}}$

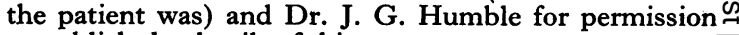
to publish the details of this case.

\section{REFERENCES}

ACkroyd, J. F. (1949): The Pathogenesis of Thrombocytopenic Purpura due to Hypersensitivity to Sedormid, Clin. Sci., 7, 249.

Beutler, E., Robson, M., and Bultenwiesser, E. (1957): The Mechanism of Glutathione Destruction and Protection in Drug Sensitive and Non-sensitive Erythrocytes. In vitro studies, $\mathcal{F}$. clin. Invest., 36, 617.

Brockhaus, L. (1958): Ein neues langwirkendes Sulfonamid in der kinderpraxis, Med. Klin., 53, 1505.

Dausset, J., Nenna, A., Tsevrenis, H., and Bernard, J. (1953): La Pancytopénie Chronique Idiopathique avec Leucoagglutinine Serique, Rev. Hémat., 8, 316.

$\longrightarrow$, and BRECY, H. (1954): Leuko-agglutinins in Chronic Idiopathic or Symptomatic Pancytopenia and in Paroxysmal Nocturnal Hæmoglobinuria, Blood, 9, 696.

Denny, H. M. and Menten, M. L. (1946): Aplastic Anæmia Associated with Sulfonamide Therapy, Amer. $\mathcal{F}$. med: Sci., $211,659$.

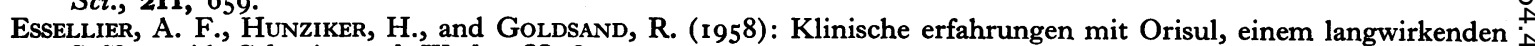
Sulfonamid, Schweiz. med. Wschr., 88, 813 .

Hirsch, E. O. and Dameshek, W. (1950): Thrombocytopenic Purpura due to Allergy to Quinidine, Amer. $\mathcal{F}$. Med., $\infty$ 9, 828 .

Holsinger, D. R., Hanlon, D. G., and Welch, J. S. (1958): Fatal Aplastic Anæmia following Sulfamethoxypyridazine Therapy, Proc. Mayo Cli., 33, 679.

Johnson, E. E., Matthews, M. J., and Stollerman, J. H. (1959): Use of Weekly Oral Doses of Sulfamethoxypyridazine for Rheumatic Fever Prevention, $\mathcal{F}$. Pediat., 54, 468.

Johnson, F. D. and Korst, D. R. (196r): Pancytopenia Associated with Sulfamethoxypyridazine Administration, J. Amer. med. Ass., r75, 967 .

Lepper, M. H., Simon, A. J., and MARienfeld, C. J. (1957): Use of Sulfamethoxypyridazine in the Prevention 웡 Streptococcal Infections in Rheumatic Patients, Ann. N.Y. Acad. Sci., 69, 485 .

Matoth, Y., Elian, E., Nelken, D., and Nevo, A. D. (1956): Specificity of Lytic Factors for Erythrocytes, Leukocytę and Platelets in a Case of Pancytopenia, Blood, Ir, 735.

Meyer, L. M. and Perlmutter, M. (1942): Aplastic Anæmia due to Sulfathiazole, f. Amer. med. Ass., r19, 558.

Moeschlin, S., Siegenthaler, W., Gasser, C., and Hassig, A. (1954): Immunopancytopenia Associated with Incomplete Cold Hemagglutinins in a Case of Primary Atypical Pneumonia, Blood, 9, 214.

NeIPP, L., PADOWETZ, W., SACKMANN, W., and TRIPOD, J. (1958): Experimentelle untersuchungen über neue sulfonamidderivate unter besonderer Berüchsichtigung der Beziehungen zwischen Blutkonzentration, Intensität und Dauer der Heilwirkung, Schweiz. med. Wschr., 88, 835 .

Osgood, E. E. (1953): Drug-Induced Hypoplastic Anemias and Related Syndromes, Ann. intern. Med., 39, r 173.

PegG, D. E. and KEMP, N. H. (1960): Collection, Storage and Administration of Autologous Human Bone-marrow, Lancet, ii, 1426.

Rentchnick, P. (I958): Nouveaux Sulfonamidés et Sulfonamidés-retard, Schweiz. med. Wschr., 88, 362.

Rosenberg, E. F. and Hench, P. S. (1946): Recent Advances in the Treatment of Rheumatic Fever with Special Reference to Sulfonamide Prophylaxis and Intravenous Salicylate Therapy, Med. Clin. N. Amer., 30, 489.

Schultz, I. and Frank, P. F. (1958): The Prophylactic Use of Sulfamethoxypyridazine during a Streptococcal Epidemic, Amer. Э. med. Sci., 236, 779.

Scott, J. L., Cartwright, G. E., and Wintrobe, M. M. (1959): Acquired Aplastic Anæmia: An Analysis of 39 Cases and Review of the Pertinent Literature, Medicine (Baltimore), 38, 1 I9.

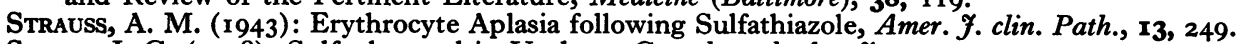

Susset, J. G. (1958): Sulfaphenazol in Urology, Canad. med. Ass. F., 79, 992.

WAGNER, K. and STERz, H. (196r): Letale panzytopenie duren sulfabutin, Klin. Med. (Wien), 16, 373.

WEINREICH VON J. and Muller, W. (1956): Immun. hämatologische unter suchungen bei panzytopenien, Acta Haemat. I6, 376.

Welch, H., Lewis, C. N., and KerLAN, I. (1954): Blood Dyscrasias, a Nation-wide Survey, Antibiot. et Chemother. (Basel), 4, 607.

Wintrobe, M. M. (196r): 'Clinical Hematology'. 9th Edition, p. 553. London: Henry Kimpton.

WhEATley, D. (1959): New Sulphonamides, Brit. med. F., ii, 694 .

WolfF, J. A. (I957): Anemias caused by Infections and Toxins, Idiopathic Aplastic Anemia and Anemia caused by Renal Disease, Pediat. Clin. N. Amer., 4, 469. 